\title{
IDENTIFIKASI SENYAWA KLORIN (CL) PADA BERAS PUTIH (ORYZA SATIVA L.) YANG BEREDAR DI KOTA MAKASSAR DENGAN METODE KUALITATIF
}

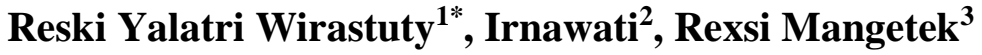 \\ ${ }^{1 *}$ STIKES Nani Hasanuddin Makassar \\ ${ }^{2}$ STIKES Nani Hasanuddin Makassar \\ ${ }^{3}$ STIKES Nani Hasanuddin Makassar \\ email: reskiyalatri89@gmail.com
}

\begin{abstract}
ABSTRAK
Beras merupakan makanan pokok yang diolah menjadi nasi yang dijadikan sebagai makanan pokok dan sumber energi bagi tubuh manusia. Adapun bahan tambahan pangan yang dilarang untuk ditambahkan pada beras yaitu senyawa klorin. Tujuan penambahan klorin pada beras yaitu untuk membuat beras terlihat lebih putih bersih dan mengkilap agar memiliki harga jual yang tinggi dalam pemasarannya. Penambahan klorin pada beras dapat membahayakan kesehatan manusia, seperti dapat mengganggu pencernaan, menurunkan sistem kekebalan tubuh, dapat menyebabkan kanker, merusak hati serta ginjal. Tujuan penelitian ini yaitu untuk mengidentifikasi adanya senyawa klorin yang terkandung dalam beras putih (Oryza sativa L.) yang beredar di Kota Makassar. Sampel pada penelitian ini berjumlah 12 sampel yang terbagai menjadi kelompok yaitu kelompok beras yang dijual bebas di pasar dan kelompok beras dengan merek berbeda dengan teknik purposive sampling. Identifiksi senyawa klorin pada beras menggunakan metode kualitatif yaitu uji reaksi warna. Hasil yang didapatkan dari 12 sampel uji yaitu tidak terjadi perubahan warna yang menandakan sampel negatif klorin dengan metode kualitatif, uji reaksi warna dengan amilum $1 \%$ dan kalium iodida $10 \%$. Sedangkan hasil dari uji reaksi warna menggunakan indikator betadine yaitu terjadi perubahan warna menjadi coklat kehitaman yang menunjukkan sampel negatif klorin. Berdasarkan hasil penelitian yang didapatkan, maka dapat disimpulkan bahwa beras yang telah diuji tidak memiliki kandungan klorin sehingga aman untuk dikonsumsi.
\end{abstract}

Kata Kunci : Beras, Klorin, Kota Makassar, Uji Reaksi Warna

\section{PENDAHULUAN}

Indonesia merupakan negara tropis dengan kondisi tumbuh padi yang ideal. Padi merupakan tanaman yang sangat berharga bagi manusia. Padi menghasilkan beras yang dijadikan sebagai sumber pangan (Utama, 2015). Beras (Oryza sativa L.) merupakan makanan utama sebagian besar masyarakat Indonesia. Dibandingkan dengan makanan pokok lainnya, beras (Oryza sativa L.) memiliki produktivitas yang tinggi dan umur simpan yang lebih lama (Nur, 2019).

Beras (Oryza sativa L.) adalah makanan pokok dan sumber energi bagi tubuh manusia. BerasSputih (Oryza sativa L.) memiliki kandungan seperti karbohidrat tinggi tetapi protein rendah. Beras tersedia dalam berbagai bentuk dan warna, termasuk beras putih, beras hitam, dan beras merah (Hernawan \& Meylani, 2016).

Dimasa sekarang ini, banyak produsen nakal yang menggunakan berbagai cara untuk memperpanjang umur simpan atau perbaiki tekstur, rasa, dan warna dari produk yang dijual khususnya pada beras putih (Oryza sativa L.). ahan lain yang digunakan dalam nasi putih (Oryza sativa L.) adalah senyawa klorin $(\mathrm{Cl})$. Klorin $(\mathrm{Cl})$ digunakan sebagai bahan pemutih pada beras (Oryza sativa
L.) agar terlihat lebih mengkilat. Klorin $(\mathrm{Cl})$ bisa dalam bentuk bubuk, cair dan tablet (Rahmi, 2016).

Klorin $(\mathrm{Cl})$ adalah suatu senyawa kimia yang berfungsi sebagai pemutih di pabrik pakaian dan kertas serta dipakai untuk membunuh kuman. Banyak juga yang menggunakan klorin $(\mathrm{Cl})$ sebagai komponen pemutih larutan pembersih hingga pemutih air kolam renang. Klorin $(\mathrm{Cl})$ yang bereaksi dengan air akan menghasilkan asam hipoklorus dan apabila di konsumsi akan membahayakan kesehatan tubuh. Dampak yang akan ditimbulkan dari senyawa klorin $(\mathrm{Cl})$ tergantung pada jenis senyawa klorin $(\mathrm{Cl})$, tingkat toksisitas senyawa tersebut serta kadar pada senyawa klorin $(\mathrm{Cl})$ (Rahmi, 2016).

Beberapa pengaruh klorin $(\mathrm{Cl})$ yang dapat mempengaruhi kesehatan manusia seperti mengganggu pencernaan, menurunkan sistem kekebalan tubuh, dapat menyebabkan kanker, merusak hati serta ginjal, menganggu sistem saraf, dan gangguan sistem reproduksi yang dapat menyebabkan keguguran (Rahmi, 2016).

Penelitian (Aminah, 2019) tentang Analisis Kandungan Klorin Pada Beras Yang Beredar Di Pasar Tradisional Makassar Dengan Metode Argentometri Volhard menunjukkan dari 8 sampel yang diteliti, terdapat 3 sampel beras (Oryza sativa 
L.) yang positif mengandung senyawa klorin(Cl). Kemudian pada penelitian (Sudarma et al., 2018) tentang Pemanfaatan Betadine Sebagai Indikator Uji Klorin Pada Beras Berpemutih, hasil yang ditemukan 2 jenis beras (Oryza sativa L.) positif mengandung klorin $(\mathrm{Cl})$ dari 10 sampel yang diteliti.

Berdasarkan uraian diatas, dapat dilihat bahwa senyawa klorin (Cl) sangat berbahaya jika digunakan untuk pemutih beras (Oryza sativa L.), sehingga peneliti tertarik untuk melakukan penelitian tentang identifikasi senyawa klorin $(\mathrm{Cl})$ pada beras putih (Oryza sativa L.) yang beredar di Kota Makassar dengan metode kualitatif.

\section{METODE}

Jenis, metode, lookasi, populasi, dan sampel penelitian. Jenis penelitian penelitian ini adalah observasi di Laboratorium, dengan menggunakan metode kualitatif. Penelitian ini dilakukan di Laboratorium Kimia STIKES Nani.

Sampel yang digunakan dalam penelitian ini sebanyak 12 sampel beras yang dibagi 2 kelompok, yakni kelompok tanpa merek yang dijual bebas di pasar dan kelompok yang memiliki merk. Penarikan sampel dilakukan dengan teknik purposive sampling yang berdasarkan dengan kriteria :

a. Beras putih dalam kemasan yang bermerk

b. Beras yang dijual bebas di pasaran (tanpa merk)

c. Beras berwarna putih dan mengkilap

d. Tekstur beras agak licin.

\section{HASIL PENELITIAN}

Penelitian dengan judul identifikasi senyawa klorin (cl) pada beras putih (oryza sativa 1.) yang beredar di kota makassar dengan metode kualitatif dilaksanakan pada tanggal 21-28 Juni 2021 di laboratorium kimia stikes nani hasanuddin Makassar.

Table 1. Hasil Pengamatan

\begin{tabular}{|c|c|c|}
\hline \multirow{2}{*}{$\begin{array}{l}\text { Inisial } \\
\text { Merek } \\
\text { Dagang }\end{array}$} & $\begin{array}{c}\text { Amilum 1\%+ } \\
\text { Kalium Iodida } \\
10 \%\end{array}$ & $\begin{array}{c}\text { Indikator } \\
\text { Betadine }\end{array}$ \\
\hline Kios A & Putih keruh (-) & $\begin{array}{c}\text { Coklat kehitaman } \\
(-)\end{array}$ \\
\hline Kios B & Putih keruh (-) & $\begin{array}{c}\text { Coklat kehitaman } \\
(-)\end{array}$ \\
\hline Kios C & Putih keruh (-) & $\begin{array}{c}\text { Coklat kehitaman } \\
(-)\end{array}$ \\
\hline Kios D & Putih keruh (-) & $\begin{array}{c}\text { Coklat kehitaman } \\
(-)\end{array}$ \\
\hline SB & Putih keruh (-) & $\begin{array}{c}\text { Coklat kehitaman } \\
(-)\end{array}$ \\
\hline MJ & Putih keruh (-) & $\begin{array}{c}\text { Coklat kehitaman } \\
(-)\end{array}$ \\
\hline MB & Putih keruh (-) & $\begin{array}{c}\text { Coklat kehitaman } \\
(-)\end{array}$ \\
\hline
\end{tabular}

\begin{tabular}{|c|c|c|}
\hline LP & Putih keruh (-) & $\begin{array}{c}\text { Coklat kehitaman } \\
(-)\end{array}$ \\
\hline PR & Putih keruh (-) & $\begin{array}{c}\text { Coklat kehitaman } \\
(-)\end{array}$ \\
\hline RJ & Putih keruh (-) & $\begin{array}{c}\text { Coklat kehitaman } \\
(-)\end{array}$ \\
\hline PM & Putih keruh (-) & $\begin{array}{c}\text { Coklat kehitaman } \\
(-)\end{array}$ \\
\hline KL & Putih keruh (-) & $\begin{array}{c}\text { Coklat kehitaman } \\
(-)\end{array}$ \\
\hline
\end{tabular}

\section{Keterangan :}

1. Uji reaksi warna dengan amlium $1 \%$ dan kalium iodida $10 \%$

Positif (+) : Biru

2. Uji reaksi warna dengan indikator betadine Positif (+) : Putih keruh

\section{PEMBAHASAN}

Pada penelitian identifikasi senyawa klorin $(\mathrm{Cl})$ pada beras putih (Oryza sativa L.) yang beredar di kota Makassar digunakan 12 sampel yang terbagai menjadi 2 kelompok yaitu kelompok beras tanpa merek yang dijual bebas di pasar (Kios A, Kios B, Kios C, Kios D) dan kelompok beras yang menggunakan merek (SB, MJ, MB, LP, PR, RJ, $\mathrm{PM}$ dan $\mathrm{KL}$ ).

Identifikasi senyawa klorin $(\mathrm{Cl})$ pada beras putih (Oryza sativa L.) yang beredar di kota Makassar digunakan 2 metode yaitu uji reaksi warna dengan menggunakan indikator amilum $1 \%$ dan kalium iodida $10 \%$ jika terjadi perubahan warna biru menandakan sampel positif mengandung klorin $(\mathrm{Cl})$, sedangkan dengan menggunakan indikator betadine jika tidak terjadi perubahan warna (putih keruh) menandakan sampel positif mengandung klorin.

Penelitian ini sejalan dengan penelitian (Rahmi, 2016) uji reaksi menggunakan indikator amilum $1 \%$ dan kalium iodida $10 \%$, dari 10 sampel dengan 5 jenis beras berbeda yang diambil dari 2 pedagang hasil yang didapatkan semua negatif mengandung klorin (Cl). Begitupun dengan penelitian (Wongkar, I.Y., Abidjulu, J. dan Wehantouw, 2014) dari 9 sampel beras yang di ambil dari 3 pasar berbeda juga negatif mengandung klorin $(\mathrm{Cl})$ karena tidak mengalami perubahan warna.

Percobaan selanjutnya adalah uji reaksi dengan indikator betadine, yang dilakukan dengan menimbang 10 gram sampel uji dan dimasukkan ke dalam erlenmeyer, kemudian ditambahkan $10 \mathrm{ml}$ aquadest dan disaring, dipipet setiap sampel uji sebanyak $2 \mathrm{ml}$. filtrat, dan terakhir menambahkan 1 tetes indikator betadine ke dalam filtrasi. Berdasarkan uji reaksi warna menggunakan indikator betadine dari 12 sampel dengan inisial Kios A, Kios B, Kios C, Kios D, SB, MJ, MB, LP, $\mathrm{PR}, \mathrm{RJ}, \mathrm{PM}$ dan KL hasil yang didapatkan adalah terjadi perubahan warna menjadi coklat kehitaman 
yang menandakan sampel negatif mengandung klorin $(\mathrm{Cl})$.

Hal ini tidak sejalan dengan penelitian (Sudarma et al., 2018) pada uji reaksi warna menggunakan indikator betadine, dimana dari 10 jenis beras bermerek dan tidak bermerek terdapat 2 jenis beras positif mengandung klorin $(\mathrm{Cl})$ karena tidak terjadi perubahan warna (putih keruh) dan 8 sampel beras negatif mengandung klorin karena terjadi perubahan warna menjadi biru kehitaman.

Beberapa kriteria yang perlu diperhatikan dalam memilih beras yang baik (Oryza sativa L.), antara lain butir beras yang utuh (tidak banyak pecah), berwarna putih dan memiliki bintik-bintik putih khas beras, kasar dan tidak licin, serta memiliki aroma beras yang khas (tidak berbau dan berasa apek).

\section{KESIMPULAN}

Dari hasil penelitian identifikasi senyawa klorin (Cl) pada beras putih (Oryza sativa L.) yang beredar di kota Makassar, dapat disimpulkan bahwa dari 12 sampel yang telah diuji, semua sampel dinyatakan tidak mengandung klorin $(\mathrm{Cl})$. Pada pengujian dengan kalium iodida $10 \%$ dan amilum $1 \%$ semua sampel yang telah diuji tidak menunjukkan perubahan warna (putih keruh) yang menandakan sampel negatif klorin $(\mathrm{Cl})$. Kemudian, pada pengujian dengan indikator betadine, semua sampel yang diuji mengalami perubahan warna coklat kehitaman, yang menandakan sampel negatif klorin. Hal ini menunjukkan bahwa beras (Oryza sativa $\mathrm{L}$.) yang telah diuji aman untuk dikonsumsi.

\section{SARAN}

Diharapkan kepada masyarakat agar lebih berhati-hari dalam memilih beras yang dikonsumsi, agar mendapatkan beras yang bebas dari zat berbahaya seperti klorin $(\mathrm{Cl})$ yang dapat menganggu kesehatan tubuh.

\section{DAFTAR PUSTAKA}

Aminah, S. (2019). Analisis Kandungan Klorin pada Beras yang Beredar Di Pasar Tradisional Makassar Dengan Metode Argentometri Volhard. 0-2. https://doi.org/10.31219/osf.io/v5s62

Hernawan, E., \& Meylani, V. (2016). Analisis Karakteristik Fisikokimia Beras Putih, Beras Merah, Dan Beras Hitam (Oryza sativa L., Oryza nivara dan Oryza sativa L. indica). Jurnal Kesehatan Bakti Tunas Husada: Jurnal Ilmu-Ilmu Keperawatan, Analis Kesehatan Dan Farmasi, 15(1), 79. https://doi.org/10.36465/jkbth.v15i1.154

Nur, L. (2019). Mengenal Tanaman Makanan Pokok. ALPRIN.

Rahmi. (2016). Identifikasi Kualitatif Klorin Pada Beras Yang Diperjualbelikan Di Pasar. 2(1), $72-77$.

Sudarma, N., Idayani, S., \& Setiawan, D. (2018). Klorin Pada Beras Berpemutih Utilization Of Betadine As A Chlorine Test. 5(2), 157-164.

Utama, Z. R. (2015). Budidaya Padi Pada Lahan Marjal: Kiat Meningkatkan Produksi Padi. Andi.

Wongkar, I.Y., Abidjulu, J. dan Wehantouw, F. (2014). Analisis Klorin Pada Beras Yang Beredar di Pasar Kota Manado. Jurnal Ilmiah Farmasi. Program Studi Farmasi FMIPA UNSRAT: Manado. Jurnal Ilmiah Farmasi, 3(3), 342-346. 